The Sustainable City XII 73

\title{
CONSIDERING NEW URBANISM, NEW RURALISM AND GREEN URBANISM IN RESPONSE TO MULTIFUNCTIONALITY: THE CASE OF VERKYKERSKOP, SOUTH AFRICA
}

\author{
JAKO VIVIERS, SELNA G. CORNELIUS \& ELIZELLE J. CILLIERS \\ Urban and Regional Planning, Research Unit for Environmental Sciences and Management, \\ North-West University, South Africa
}

\begin{abstract}
Paul Davidoff charged planners in 1965, as a profession making urban life more beautiful, exciting, creative and more just, as having little to say. The task thereupon was to train a generation of planners to go well beyond the designers of the sixties in their ability to prescribe future urban life. Nijkamp, in 1980, affirms the utopians' claim that the future is open and flexible, and that every development in the community, could imply a surprising step towards something better. A half century since Davidoff's indications, planners encounter ever expanding planning approaches, "towards something better", ranging from compact cities, transit oriented developments, new urbanism, new ruralism, shared cities, to smart growth and, of late, green urbanism and eco-cities; all in response to multifunctionality. Although the concept of multifunctionality has gained increasing attention the last decade, there is much frustration amongst planners regarding a proper set of broadly based definitions and clear statements concerning its scientific points of departure. This research argues that a combination of planning approaches are a more suitable response in attaining multifunctional land use; especially as megatrends underscore the need for moving away from seeking a predictable single future or outcome. The uniqueness of the Southern African landscape, inherently being rural, necessitated a rural accentuation on multifunctionality. Applying theory-based sampling as part of qualitative inquiry into the recently planned rural village of Verkykerskop, acclaimed by the Charter for New Urbanism in 2012, it is questioned whether the reciprocal employment of planning approaches induced multifunctional rural land use. Offering a design philosophy, whereby "farming, playing and living" is attained through the combined appliance of new urbanism, rural urbanism and green urbanism in planning the rural village, conclusions are drawn relating to the conduciveness of these approaches in achieving multifunctional rural land use.
\end{abstract}

Keywords: multifunctionality, multifunctional land use, multifunctional rural land use, new urbanism, new ruralism and green urbanism.

\section{INTRODUCTION}

Paul Davidoff charged planners in 1965 [1], as a profession making urban life more beautiful, exciting, creative and more just, as having little to say. In prescribing future urban life, the obligation was to ensure a generation of planners to surpass the designers of the sixties. Nijkmap [2], affirms the utopians' claim that the future is open and flexible, and that every development in the community, could imply a surprising step towards something better. A half century since Davidoff's indications, integrated planning approaches "towards something better" echo extensively across the different fields [3], of compact cities, transit oriented developments, new urbanism, new ruralism, shared cities, mixed land use to smart growth and, of late, green urbanism and eco-cities; all likely responses to multifunctionality. These approaches prolong the methodologies of the sixties, where urban development and design was known by Jacobs [4], as homogeneous development leading to spatially separated residential-working and commercial areas. It was affirmed by Katz et al. [5], in 1994, that the suburban paradigm that has dominated since the 1940s and 1950s, will not be able to 
meaningfully sustain another generation of growth. In intercepting this phenomenon, and in response to homogeneous approaches, multifunctionality is offered to contemporary planners as a holistic solution to development and redevelopment, where this perspective seems to enjoy prominence [6]. The research of Dijst et al. [7], emphasise that traditional planning policies are no longer suitably addressing the demands, stemming from a diverse group of actors, typically found in rural areas. In considering future rural life, Kopeva et al. [8], underlines that multifunctional land use plays a significant role in attaining sustainable development and elaborates that a multifunctional approach, combining economic with ecological principles, augments economic results in peri-urban and rural areas. This paper considers the reciprocal implementation of three planning approaches, new urbanism, new ruralism and green urbanism, to reflect on multifunctionality and draws preliminary conclusions with regard to the case of Verkykerskop, a rural village set in a unique rural South African landscape, and the conduciveness of these approaches in achieving multifunctional rural land use.

\section{UNDERSTANDING MULTIFUNCTIONALITY}

\section{Most of us have some favourite landscape, M.E. Hardy, 1913}

Restructuring is high on the agenda in South Africa, as the recently promulgated Spatial Planning and Land Use Management Act, Act 16 of 2013, requires planners to to grapple rural revitalisation [9]. Coupled with the all too familiar occurrence, described by Keneley [10] as the "dying town syndrome", the imagination of planners is captured, angling them towards multifunctionality as a promising perspective to implement in revitalising the rural landscape. Although the concept of multifunctionality has gained increasing attention in the last decade, there is copious frustration amongst planners regarding a proper set of broadly based definitions and clear statements concerning its scientific points of departure [11]. A prelude to the complexity of multifunctionality is presented by the research of Batty et al. [12], cautioning "that the whole concept of multifunctionality and mixed use is more convoluted spatially than its discussion implies". It is perceived by them as a theme running through many substantive discussions of the contemporary urban scene. Attempting to frame a structured point of departure, Brandt et al. [6] postulate a similar complex three tier approach, defining multifunctionality as (i) spatially combining separate land parcels, differing in function, (ii) applying different functions to the same land parcel, but at different times and (iii) applying different functions to the same land parcel but at the same time. Multifunctionality, it seems, proposes the intertwining or combining of different functions by utilising limited space more effectively [13]. The combination of functions should, amongst others, offer increased health and wellbeing benefits for the public and equally secure intact ecological systems [14]. In associating with this interpretation, Vreeker [15], comprehends multifunctional land use as a form of urban development where different land uses are concentrated in a specific area and comprising synergy amongst the combined land use functions.

Far from the partisan agricultural perception of multifunctionality, Wilson [62], takes a step in a different direction by presenting its broader application, to include, inter alia, the "production" of social functions and social capital. Social capital in its expansive terms implies the networks of relationships among people who live and work in a particular society, enabling its effective functioning [11]. He points social capital out, as an impetus for the ultimate creation of social resilience and that multifunctionality, amongst other, is attainable when environmental, economic and social capital are in equilibrium. The leitmotif of Schama 
[64], is simply that "landscapes are culture before they are nature". Hansen and Pauleit [16], lament that multifunctionality should not be understood in a meagre measurable sense of "the more functions the better", but rather as is a normative approach, implying a broader view on urban areas, being "interrelated social-ecological systems"; a perspective deemed essential to inform the design of planning processes. This perspective is standing in stark contrast with times, when urban development and design, was known to be homogeneous and where planning lead to spatially disconnect residential, working- and commercial areas [4]. In response to homogeneous approaches, multifunctionality is offered as a planning concept for contemporary planners to attain interactive environments, generate social cohesion and economic benefits to the rural community [23]. This discussion is concluded by Nelson [35], in laying claim, that just as the physical landscape is examined, the social landscape must similarly be examined.

This paper consequently pursues a combination of planning approaches as an apposite response in attaining multifunctional land use; especially as megatrends underscore the need for moving away from seeking a predictable single future or outcome [17]. In the contemporary planning fraternity, urban development and design enjoy great focus considering a more holistic approach to development and redevelopment, where multifunctional planning approaches are highly applicable and also serve as a condition for sustainable development [6]. The denotation of multifunctionality infers that the landscape provides multiple material and immaterial goods to meet societal demands and processing of the landscape. Wiggering et al. [18], in this regard, specifically illustrates how land use affect landscape functions and how they satisfy the multiple demands society places on the use and services of the landscape and further suggests that landscape functions should also include biodiversity and habitat functions. De Groot [19], directly relates to this assumption, appositely arguing for a thorough analysis of the ecological, socio-cultural and economic values of the landscape in planning and decision-making, causative towards multifunctional landscapes. In attaining these landscapes, he deems the involvement of local people as significant and their role to be effectively communicated to planners and decision makers. In supporting, and by emphasising the significance of the economic advantages, Balmford et al. [20], maintain that the multifunctional and sustainable use of natural landscapes, typically surpasses the "gains of their conversion to single-purpose land use types". Collaborative planning amongst economists, ecologists, social scientists and planners (and local people) is stoutly advocated by researchers to obtain understanding in the compromises involved in land use change decisions.

The concept of multifunctionality should conversely be context driven. The uniqueness of the Southern African landscape, inherently being rural, necessitates a rural accentuation on multifunctionality [22]. Nonetheless, it is alarming that despite the proven economic value of the multifunctional use of the natural environment, its large-scale destruction and degradation in the South African rural landscape, is imminent [21]. The increasing pressure on land, if an efficient spatial planning approach is not implemented and improving multifunctional land use is not timely found will, according to Djist et al. [7], result in conflicts and loss of environmental quality. These pressures relate to demographic and lifestyle changes, increased mobility, the growing need for housing in nature, landscape and recreational space conversion and the demand on rural space for water. The challenges for multifunctional land use are highlighted by the research of Pallarès-Blanch et al. [24] and Bielsa et al. [25], contemplating agricultural abandonment and countering it through "naturbanization" (an approach, perhaps, to some extent, related to new ruralism); a process of attracting residential dwellers towards near protected natural and rural areas, thereby 
changing the socio-demographic and economic structure, the form of settlements and agricultural landscapes. The causes for changing residential preferences by opting for "suburban or ex-urban residential environments" are concluded by Aurdirac et al [26], as "...the ideal of owning a single family home, the need for an adequate environment for raising a family, a strong desire for privacy and the appeal of a rural ambience...".

In explaining the rural landscape's transition to multifunctional land use, the research of Vereijken [27], recommends physical and economic restructuring thereof; in principle proposing "dualistic planning", firstly designating areas for "openness, quietness and silence" focusing on nature, recreation, cultivated farms and grazing and secondly designating areas for "main road" functions, permitting living, soft (retailers and services) and hard enterprises (production, trade and transport). In preparing an analysis, the structural arc of this paper ensues new urbanism, new ruralism and green urbanism as probable building blocks in response to multifunctionality and in suggesting the rural landscape's conversion to multifunctional land use.

\section{INTERFACING NEW URBANISM, NEW RURALISM AND GREEN URBANISM}

The dossier of scholars, independently contemplating the planning approaches of new urbanism, new ruralism and green urbanism and its relevance to urban and rural landscapes, appears full, but in contrast with a shorter list of thinkers, seeking the collective interface between all three approaches. The difficulty of translating new urbanism principles in the new ruralism philosophies, is lamented by Newman and Saginor [28], indicating that rural communities often encounter the integration of new urbanism concepts in low-density environments as demanding. In a similar attempt, Lehmann [29], firstly by comparing the definitions of new urbanism and green urbanism, then targeting a set of holistic principles for green urbanism, perceives "eco-city theory" as the future of urbanism and the city itself. In turn, the research of Jepson and Edwards [30], advocates that planners notice new urbanism, smart growth and the ecological city as complex approaches to prepare development strategies for, although the ecological city approach was found to be more complementary to the other two. His findings suggest the planning profession's responsibility to outline a hybrid methodology, prompting this research, in combining a trio of seemingly intertwined planning approaches. The necessity to reciprocally apply more than one planning approach, or a combination of approaches, is promoted by Trudeau [31], as he, similar to Jepson and Edwards [30], identifies a "hybrid urbanism", describing low-density projects and selecting the attributes of new urbanism in conjunction with other design features that typify conventional forms of development. Given planners' position of influence "towards something better", an awareness of the limitations of the approaches of new urbanism, new ruralism and green urbanism, and a clearer sense of collectively defining and correlating them, may well be conducive towards a hybrid approach and a more sustainable development pattern.

Kraus [32], identifies new ruralism as a framework, bridging sustainable agriculture and new urbanism, suggesting an equivalent with new urbanism's vision of compact, mixed-use urbanised areas, the elimination of low density, auto-dependent sprawl, and distinct edges between towns and their surrounding rural and agricultural areas. Highlighted by several scholars, agricultural preserves may well present itself in the form of green food belt perimeters, buffers between city and rural lifestyles, countryside residences, small agricultural parks in the urban-rural interface or bigger preserves further afield, including larger farms and rural settlements. Several researchers [6], [28], [32]-[35] regard this 
combination of functions, in the same spatial unit, aside their status as "spatially well-defined or diffused", as conducive to the multifunctional landscape.

\subsection{New urbanism}

New urbanism, as a planning approach, offers diverse dimensions ranging from its direct development principles to laying foundations for social goals and may well be viewed as an already multiple approach to planning. Muschamp [36], formerly described new urbanism as "the most important phenomenon to emerge in American architecture in the post-Cold War era". He further affirms that the Congress for the New Urbanism started out with an unpretentious approach to, amongst others, model new suburban developments on the compact scale of small towns, increase residential development density, placing urban amenities within walking distance of houses and positioning plans toward pedestrians and public transportation. It was later defined as the creation and restoration of walkable, compact, mixed-use communities, arranged in a manner that its components are still based on conventional development, but assembled in a more integrated fashion; all of which are argued to counteract sprawl and reduce car dependence [37]. Mayo and Ellis [38] added that new urbanism additionally values community, civility, a sense of place, beauty, equity and sustainability, not necessarily reflected upon in conventional planning approaches. In seeking a relationship between design principles and social goals, Talen [39], underscores the Charter principles, applied to social goals, indicating that new urbanism is primarily concerned with common good, followed by social equity and then community. Put forward by Duany and Plater-Zyberk [40], planners tend to focus on the economic and environmental consequences of the urban form, navigating from social consequences and goals. New urbanism is therefore "new", as it proposes an unusual approach to making suburbs and redeveloping cities by also placing strong emphases on its inhabitants' well-being.

In a regional context, Bohl [41], endorses its promotion of rural hamlets and villages, small towns in districts, in providing compact alternatives, applicable to different rural settings. Limited research of new urbanism in its regional form and the few new urbanist regional plans in existence, suggest that a better understanding of the different scales at which the urban form is shaped as well as the relationships that exist between elements at the different scales, will be necessary [42].

\subsection{New ruralism}

New Support for new ruralism gradually increases as scholars are observed intending to frame its definition, approaches and priorities. New ruralism, in broad, is entrenched in past models, comparable with the agricultural context of the 'Garden City' and the selfsufficiency components of agri and eco-villages. It furthermore incorporates current initiatives and mechanisms to preserve and enhance regional agriculture and natural resource. Although Nelson [35] agrees that the forces of the new ruralism are already afoot, they are only rudimentary theorised and he perceives building the new ruralism as a necessary step in "sharpening the resolution with which social scientists can describe the effect of place on people"; further adding that we should "examine the social landscape stratigraphically, peering down through all its layers to understand it as a whole".

In attempting a more refined and comprehensive definition of new ruralism, Newman and Saginor [28], recommend that it should read "clustered, small-to medium-scaled suburban style developments, occurring in rural areas, under urban influence, characterised by large 


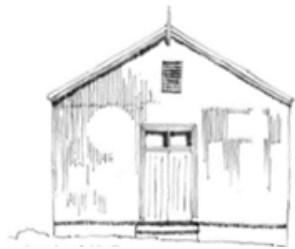

(a)

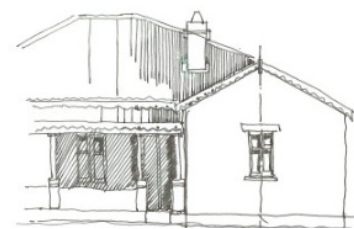

(b)

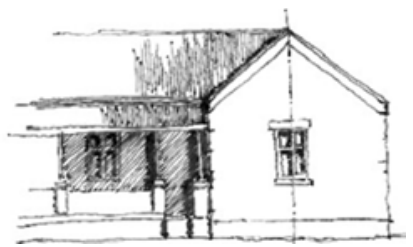

(c)

Figure 1: Façade studies of vernacular architecture. (Source: GWA Studio, 2014.)

ratios of viable preserved farmland, that contribute to local and regional food systems and help contain/sustain metropolitan regions". In attaining permanent preserves, as the primary goal of new ruralism, multiple economic opportunities, optimal preservation of farmland and green space (enabling open space networks) and ensuring stable and adaptable working farms, are also ascertained in their research. Versaci [34], agreeably claims that new ruralism ought to be viewed as the flip side of new urbanism, signalling a strategy to develop new communities in country places, offering a way to preserve the rural landscape and agricultural heritage. He describes new ruralism as a better way to develop rural areas, seeking to preserve the ambiance of a place by reinterpreting traditions, patterns and customs in designing new communities. New ruralism, at its core, considers environmental stewardship in a context of conserving (preserves) agricultural land for vernacular architectural traditions (typically illustrated in the case study of Verkykerskop in Fig. 1), wildlife habitat, natural settings and recreation, but also recognising imminent development markets, where home buyers deem the country life and its features as desirable. It, however, seems more applicable to small- to medium-scale sustainable agriculture, overlapping with areas for wildlife, habitat management and realises the opportunity for adding value to agricultural areas to permit clustered residential development [33].

A workshop aimed at developing a framework for new realism, held at the University of California, April 2006 [43], signalled the opinion of Dean Fraker, that new ruralism is a constellation of many different parts, with strong linkages between the built environment and health as well as the need to observe the urban-rural interface issues in terms of mega issues and regions. Delegates generally agreed to simply tell the story of the lifestyle, recreation and habitat benefits of a new relationship between city and country and concluded that "above all, new ruralism is not just the absence of urbanism,". Kraus [32] realises that new ruralism is an approach built on twenty years of reform in food, agriculture, and land use planning and determines that sustainable agriculture, made farmers' markets a basic town-centre amenity. During this time, new urbanism projects and smart growth initiatives have demonstrated the possibilities of creating healthier, more liveable urban centres. She therefore compares new ruralism as a corollary of new urbanism, with a related framework of principles, policies and practices.

Regarding the local agenda, Louw [44], substantiates new urbanism and "new ruralism frameworks" as potential tools for sustainable development in the rural setting of South Africa. A combined strategic approach is called for in understanding the linkages between urban and rural spaces as a mechanism to achieve suitable rural-urban linkages [45] and equality in ensuring balanced investment in urban and rural settlements, to promote linkages and eliminate urban or rural biases. Latterly the farming landscape of South Africa was skilfully divided into cities, towns and countryside; final destinations announcing the vast 
wilderness in between. Farmsteads built in the regional vernacular style were dispersed through a mainly open landscape, while small rural towns served as centres for the community. Rather than "bulldozing the countryside into oblivion", this landscape resonated Versaci's [34], assessment that the preservation developments of new ruralism draw the best of the past into the present.

\subsection{Green urbanism}

\section{The Universe is wider than our view of it, Henry David Thoreau, Walden, 1854}

Although Lafortezza et al. [14] expressed that the city region and its adjacent "wildland interface" appears to be the most useful region for the implementation of green infrastructure, attempts to ensure the incorporation of the environment and urban planning, largely accepted as "green urbanism", are not contemporary. McHarg [46], already in 1967, urged society to "give expression to the potential harmony of man-nature". He later, during 1981 [47] indicated that "ecological planning should seek to fit the consumer and the environment". In the much earlier writing Garden City of Tomorrow, Ebenezer Howard in 1902 [48] suggested green urbanism; a political and social agenda recently surfacing. The turn of the century saw a worldwide diaspora of sustainability principles into neighbourhood development [49]. It is believed that, compared to the planning approaches elaborated upon in the preceding sections, green urbanism, as a planning approach, is seen as metamorphic and presented in many forms and tributaries [16], [50], [51]. It emerged internationally as a way of understanding, how green assets and ecological systems function, as part of the infrastructural fabric that supports and sustains society and builds resilience [52]. Apart from its apparent ecological benefits, if managed properly, Tîrlă et al. [53], are assured that green infrastructure may become local tourist assets, thus enhancing the communities' economic benefits and concluded that green infrastructure is able to guarantee the self-sustainable cities of the future. In an era of rapid urbanisation, of which Africa is taking an unenviable lead of $3.5 \%$ per annum [54], principles for achieving green urbanism have to be promptly, clearly defined and adjusted.

In generalising, green urbanism theory focuses on adjusting the relationship between urban and nature and has emerged as a conceptual and theoretical basis for a new planning paradigm. Beatley and Newman [56], agree we are "desperately trying to learn how to become more sustainable, how to use less and live better, how to regenerate the ecology of the city and its bio-region and, sense of place, means something in a globalised economy, how to make a new economy out of green jobs and so forth". Planners are, however, cautioned by Tîrlă et al. [53], that the pressing dilemmas of the 21 st century have its focus on rapid exhaustion of conventional energy resources, abrupt urbanisation, pollution at various levels and global warming; all having an impact on the quality of life, consequently necessitating the reconsideration of the planning and functioning of settlements. They recommend that this reconsideration may well regard multi-disciplinary approaches, sustainability plans, environments that are quiet, clean and effective, compact communities and green transport, ecosystem services, urban greening, gardens and green roofs, city farms and urban agriculture, renewable energy projects, sense of place and lifestyle. In this respect, Nilsson et al. [57] explain that urban greening embraces the planning and management of urban vegetation on streets, parks, playgrounds, local gardens and the urban periphery, also aiming to add value to the local community. Quite by contrast, Palmer and Simon [58], argues that the world is not able to "merely afford urban sustainability utopianism". 
In view of this contrasting assertion by Palmer and Simon [58], equated with the scholarly emphasis on green urbanism, this paper contemplates whether the mere application of a single planning approach will discourse the "pressing dilemmas of the 21 st century", or will a progressive understanding of the reciprocal application of planning approaches, expand solutions through multifunctionality. Lehmann [29], is adamant that our "cities can and must become the most environmentally-friendly model for inhabiting our earth". He lays claim that it is more important than ever to rethink cities and their infrastructure, to be compact, comprising mixed-use and a high-level polycentricism. It is not simply finding technical solutions to eco-friendliness, but rather a comprehensive and holistic process of pledging principles for healthy communities. While the linkages between human well-being and environmental preservation are known, Cilliers and Cilliers [59], alert that socio-economic pressures often take precedence in the South African context. The current reality suggests that green infrastructure and green spaces are often neglected or sacrificed, affirmed by Artmann et al. [50], by also emphasising this phenomenon on a regional scale. Green urbanism is not viewed as a phenomenon confined to élite academia. Green infrastructure, ecosystem services, resilience and adaptive planning, amongst other, should form part of the common language of future planners. Green urbanism "has to become the norm for all urban developments" [29].

The ensuing Table 1 aspires to capture the interface of multifunctionality with new urbanism, new ruralism and green urbanism, based on the design principles of each planning approach. The principles of multifunctionality were purposefully selected, based on the literature captured in section 2, aiming to illustrate the possible linkages and interface with the contemplated planning approaches. The selected principles were recoded, applying a theory-based sampling methodology, into six broad thematic categories, considered inherent to multifunctionality and derived from the literature investigation, supporting this research.

\section{MULTIFUNCTIONALITY IN RURAL CONTEXT: RESPONSES FROM VERKYKERSKOP}

Applying theory-based sampling, as part of a qualitative inquiry, this paper ruminates whether the reciprocal employment of the discussed planning approaches, may well induce multifunctional rural land use. In this instance, the interpretation of Brandt and Vejre [6], is accepted that a multifunctional landscape comprises "several functions at the same time" and further listing examples such as, housing opportunities, wildlife, habitats, groundwater, climate regulation, recreational, aesthetic, cultural and spiritual values. No single paper, will conclusively contribute to the academic landscape and Table 1 should be weighed as an emergent analysis. Pertaining to interfacing, the (i) identified design philosophy and planning approaches employed during the design of Verkykerskop, (ii) relating to the multifunctional principles derived from theory-based sampling, (iii) an overlapping and correlating matrix, was prepared. Following an extensive literature review of the three planning approaches, design principles were selected pertaining to each. These were selected to enable a comparison between the unique design approaches of the case study. All the design principles were not employed, merely a purposeful selection thereof for the scope of this paper. Where these principles interfaced with the principles of multifunctionality, it was nominated as such in the prepared matrix (see Table 1). In applying this integrative approach, a synthesis of the case study and its interface with the three planning approaches, comparative to multifunctionality, is captured. The approach was further undertaken to illustrate whether the reciprocal application of the three planning approaches, was conducive to multifunctionality, in this instance, in a rural landscape. The matrix is not exhaustive and does not reflect upon the complete assessment that was endeavoured, as part of the contributing research. It is 
acknowledged as a mere illustration of the conduciveness that seems to exist as an outcome of the reciprocal application of the considered planning approaches, as promising agents to attain multifunctionality. Verkykerskop, replanned during 2012, is located in the Free State province, South Africa, between the rural towns of Harrismith, Warden and Memel. Its setting is characteristic of a predominantly agricultural region comprising, amongst others, facilities in support of the agricultural community in the form of cattle and sheep auction pens and a small community hall. Although the aim of this section is not to comprehensively

Table 1: Multifunctionality interface with design principles of new urbanism, new ruralism and green urbanism [6], [7], [11], [13]-[16], [18]-[20], [24], [25], [27], [29], [32], [59], [61].

\begin{tabular}{|c|c|c|c|c|c|c|c|c|c|c|c|c|c|c|c|c|c|c|c|c|c|}
\hline \multirow{3}{*}{\multicolumn{2}{|c|}{ 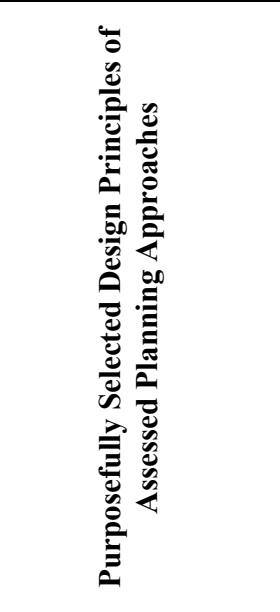 }} & \multicolumn{20}{|c|}{ Principles of Multifunctionality } \\
\hline & & \multicolumn{4}{|c|}{ Land Use } & & \multicolumn{3}{|c|}{ Ecology } & \multicolumn{4}{|c|}{ Economic } & \multicolumn{3}{|c|}{ Social } & \multicolumn{3}{|c|}{ Policy } & \multicolumn{2}{|c|}{$\begin{array}{l}\text { Produc } \\
\text {-tion } \\
\end{array}$} \\
\hline & & 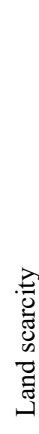 & 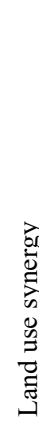 & o & & 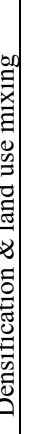 & 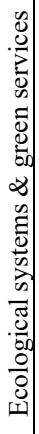 & 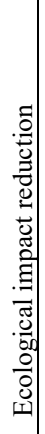 & 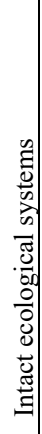 & 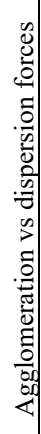 & 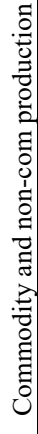 & $\begin{array}{l}0 \\
0 \\
0 \\
0 \\
0 \\
.0 \\
0 \\
0 \\
0 \\
0 \\
0 \\
0\end{array}$ & 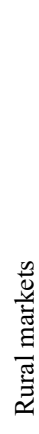 & $\begin{array}{l}\text { : } \\
\overline{0} \\
\overline{0}\end{array}$ & 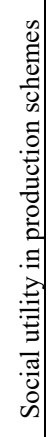 & 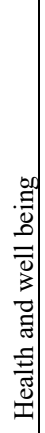 & 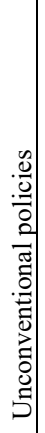 & 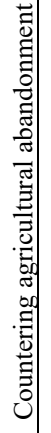 & 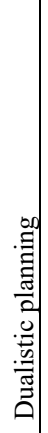 & 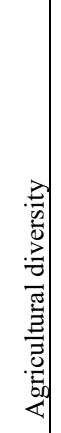 & $\begin{array}{l}0 \\
2 \\
2\end{array}$ \\
\hline \multirow{4}{*}{ 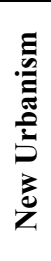 } & & 4 & 4 & 4 & & I & $\Delta$ & & 4 & 4 & 4 & 4 & 4 & & 4 & & & 4 & 4 & & 4 \\
\hline & Mixed housing & $\Delta$ & 4 & & & & 4 & 4 & $\Delta$ & & & & & & & & 4 & 4 & 4 & 4 & $\Delta$ \\
\hline & $\begin{array}{l}\text { Quality } \\
\text { architecture \& } \\
\text { urban design }\end{array}$ & 4 & & 4 & & d & $\Delta$ & 4 & 4 & & 4 & & 4 & 4 & 4 & 4 & 4 & 4 & & 4 & 4 \\
\hline & Increased density & $\Delta$ & 4 & $\Delta$ & & & $\Delta$ & & 4 & & & 4 & & & & & 4 & 4 & 4 & & $\Delta$ \\
\hline \multirow{4}{*}{ 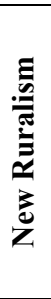 } & $\begin{array}{l}\text { Small-medium } \\
\text { scale }\end{array}$ & 4 & 4 & 4 & & $\mathbf{I}$ & $\Delta$ & & 4 & & & & & & & 4 & 4 & 4 & 4 & 4 & \\
\hline & $\begin{array}{l}\text { Overlapping } \\
\text { wildlife, habitat } \\
\& \text { recreation }\end{array}$ & 4 & 4 & 4 & & & 4 & & 4 & 4 & 4 & 4 & & & 4 & 4 & 4 & 4 & 4 & 4 & \\
\hline & $\begin{array}{l}\text { Tourism \& } \\
\text { residence }\end{array}$ & 4 & $\triangle$ & 4 & & 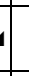 & $\Delta$ & & 4 & 4 & & 4 & 4 & 4 & & 4 & 4 & 4 & 4 & & 4 \\
\hline & $\begin{array}{l}\text { Comprehensive } \\
\text { plan }\end{array}$ & 4 & 4 & 4 & & & $\Delta$ & 4 & & 4 & 4 & 4 & 4 & 4 & 4 & 4 & 4 & 4 & 4 & 4 & 4 \\
\hline \multirow{4}{*}{ 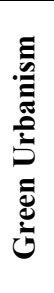 } & $\begin{array}{l}\text { Renewable } \\
\text { energy }\end{array}$ & & & & & & $\Delta$ & 4 & 4 & & & 4 & & & & 4 & & & 4 & & 4 \\
\hline & $\begin{array}{l}\text { Density \& } \\
\text { retrofitting }\end{array}$ & 4 & 4 & 4 & & & $\Delta$ & & 4 & & & 4 & & & & & 4 & 4 & 4 & & 4 \\
\hline & $\begin{array}{l}\text { Green buildings } \\
\& \text { passive design }\end{array}$ & 4 & & 4 & & $\mathbf{4}$ & $\triangle$ & 4 & 4 & & 4 & & 4 & 4 & 4 & 4 & 4 & 4 & & 4 & 4 \\
\hline & $\begin{array}{l}\text { Cultural } \\
\text { heritages/sense } \\
\text { of place }\end{array}$ & & & & & & $\boldsymbol{\Delta}$ & 4 & & & & & & 4 & & 4 & & 4 & 4 & & \\
\hline
\end{tabular}


deliberate on all the selected interfaces, a brief discussion will follow, demonstrating certain applications of the planning approaches in Verkykerskop, responding to multifunctionality.

From the onset, replanning of the village embraced new urbanism, incorporating new and innovating planning tactics, bidding the interception of the rural town's dying syndrome reprimands [10], but not destroying its rural ambiance. This was attained by inserting focus on historic buildings, landmarks, continued agricultural activities, intact ecosystems and pristine views. A dualistic planning approach followed, identifying "openness, quietness and silence" related areas and "main road" functions [27]. Findings resultant of this approach were comprehensively described in the Green Living Compendium [60], that was prepared for the village; furthermore, including a comprehensive development plan [32]. In optimally utilising scarce land [15], a mere 50 ha of land is earmarked for the replanned village (including the existing settlement), as the remaining farm (measuring 800 ha in extent), perseveres with diverse agricultural activities [11]. Sustainable agricultural and environmental management [19], were integrated into the larger fabric of the village and its surrounding rural landscape in preparing its "green framework" (Fig 2(a)), that delivers a combination green open space [29], productive open space, productive streets, urban and rural productive space and a matrix reflecting on projected ecosystem services, inclusive of green, grey and blue infrastructure. Consequently densification [15] and mixed land use were attained by intertwining different functions in limited space [59].

The proposed residential component [24], [25], pertinently reflecting the regions' vernacular architecture (Fig. 1), is measurably not monofunctional and commodity and non-commodity [11], production (Fig. 2(b)) and processing (Fig. 3 (b)) are permitted. All buildings are pre-planned [60], incorporating energy-efficiency [6] and employing green architecture and ecosystem services (Fig. 3 (a)) [14]. In denoted areas, guest houses are intrinsically permitted [29], augmenting the region's tourism basis [53].

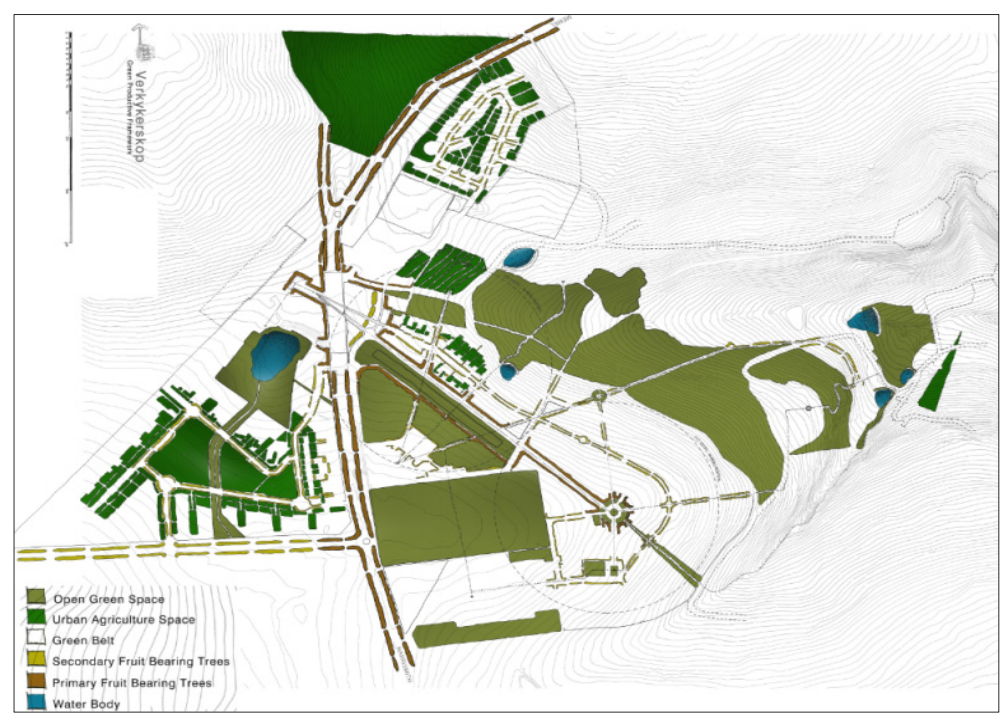

a)

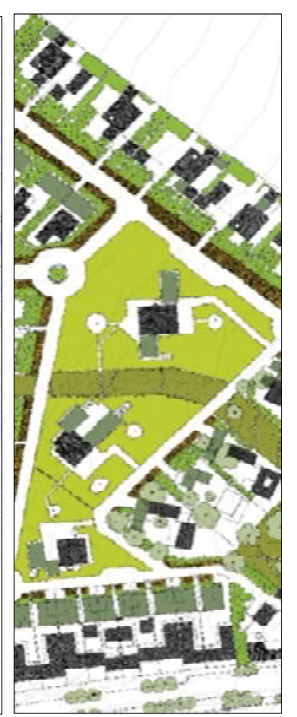

b)

Figure 2: Green framework (a); Production and processing in the residential component (b). (Source: GWA Studio, 2014.) 


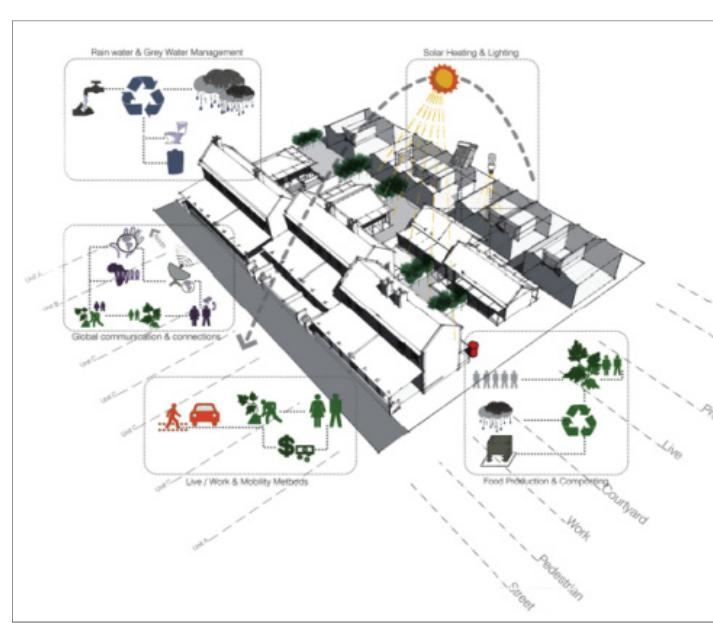

a)

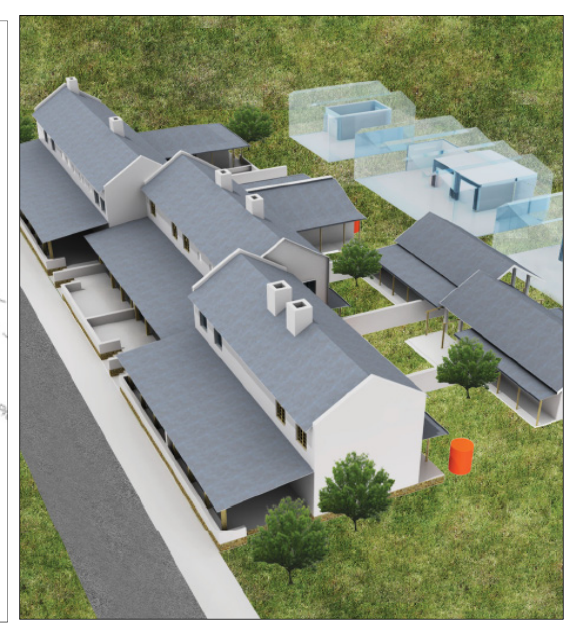

b)

Figure 3: Residential green services, renewable energy (a); Production and processing residential land use options (b). (Source: GWA, Studio, 2014.)

Synergy is additionally created by assigning permissible live-work and live-commercial (Fig. 3 (b)), residential options [15]; all by introducing non-conventional land use management policies [7]. This discussion is simply indicative of a substantial analysis that was endeavoured of the case study, signalling that further papers should be anticipated that will aim at discussing the attainment of multifunctionality in this specific and unique case study, as a corollary of reciprocally applying a trio of planning approaches.

\section{CONCLUSION}

As a consequence of the continuous pressures exerted on rural landscapes, it may well be concluded that traditional planning policies are no longer suitably addressing the demands of actors, typically found in these areas and that an increasing need for hybrid [30], [31] and integrated planning approaches is required [7]. The case study illustrated that rural landscapes comprise the potential to accommodate multifunctionality; especially by pursuing interfaces between the applied planning approaches. Finding interfaces amongst new urbanism, new ruralism and green urbanism may well inform multifunctional land use. The creation of multifunctional landscapes, as an essential constituent of future rural life, ought to be a traversing theme, attainable amidst various planning approaches, driven by the numerous benefits conducive to the revitalisation of rural areas. Refining the interfaces applicable to the rural context, is the exciting charge forward.

\section{REFERENCES}

[1] Davidoff, P., Advocacy and pluralism in planning. Journal of the American Institute for Planners, 31(4), pp. 331-338, 1965.

[2] Nijkmap, P., Herfsttij der Vooruitgang, Uitgeverij de Vuurbraak bv Groningen: Netherlands, p. 241, 1980.

[3] Tornberg, P., Making sense of integrated planning - challenges to urban and transport planning processes in Sweden. Stockholm: Royal Institute of Technology, (Thesis - PhD), p. 3, 2011. 
[4] Jacobs, J., The Death and Life of Great American Cities, Random House: New York, p. 32, 1961.

[5] Katz, P., Vincent, S., Bressi, W., Calthopre, P., Duany, A., Todd W., Plater-Zyberk, E., Moule, E. \& Polzoides, S., The New Urbanism, McGraw-Hill, New York, pp. 1245, 1994.

[6] Brandt, J. \& Vejre, H., Multifunctional landscapes - motives, concepts and perceptions. (In Brandt, J. \& Vejre, H. eds. Multifunctional landscapes: Volume 1 theory, values and history, WIT Press: Southampton and Boston, pp. 3-32, 2004.

[7] Dijst, M., Elbersen, B. \& Willis, K., The challenge of multi-functional land use in rural areas. Journal of Environmental Planning and Management, 48(1), pp. 3-6, 2010.

[8] Kopeva, D., Peneva, M. \& Madjarova, S., Multifunctional land use: is it a key factor for rural development. 118th Seminar of the European Association of Agriculture Economists. 25-27 Aug., Ljubljana Slovenia, p. 10, 2010.

[9] South Africa, Spatial Planning and Land Use Management Act, Act 16 of 2013, 2013.

[10] Keneley, M., The dying town syndrome: a survey of urban development in the western district of Victoria 1830-1930. The Electronic Journal of Australian and New Zealand History, http://dro.deakin.edu.au/eserv/DU:30002410/keneley-dyingtownsyndrome2004.pdf. Accessed on: 25 Jun. 2017.

[11] OECD, Multifunctionality: towards an analytical framework, Paris: OECD Publications, 2001.

[12] Batty, M., Besussi, E., Maat, K. \& Harts, J.J., Representing multifunctional cities: density and diversity in space and time. Built Environment, 30(4), pp. 324-337, 2011.

[13] Ahern, J., From fail-safe to safe-to-fail: Sustainability and resilience in the new urban world. Landscape and Urban Planning, 100(4), pp. 241-343, 2011.

[14] Lafortezza, R., Davies, C., Sanesi, G. \& Konijnendijk, C.C., Green infrastructure as a tool to support spatial planning in European regions. iForest, 6, pp.102-108, 2013.

[15] Vreeker, R., Urban multifunctional land use and externalities, European Regional Science Association Conference. Vienne, Autriche, pp. 1-18, 2004.

[16] Hansen, R. \& Pauleit, S., From multifunctionality to multiple ecosystem services? A conceptual framework for multifunctionality in green infrastructure planning for urban areas. Ambio, 43, pp. 516-529, 2014.

[17] Retief, F., Bond, A., Pope. J., Morrison-Saunders, A. \& King, N., Global megatrends and their implications for environmental assessment practice. Environmental Impact Assessment Review, 61, pp. 52-60, 2016.

[18] Wiggering, H., Dalchow, C., Glemnitz, M., Helming, K., Müller, K., Schultz, A., Stachow, U. \& Zander, P., Indicators for multifunctional land use - linking socioeconomic requirements with landscape potentials. Ecological Indicators, 6, pp. 238249, 2006.

[19] De Groot, R., Function-analysis and the valuation as a tool to assess land use conflicts in planning for sustainable, multi-functional landscapes. Landscape and Urban Planning, 75, pp. 175-186, 2005.

[20] Balmford, A., Bruner, A., Cooper, P., Constanza, R., Farber, S., Green, R.E., Jenkins, M., Jefferiss, P., Jessamy, V., Madden, J., Munro, K., Myers, N., Naeem, S., Paavola, J., Rayment, M., Rosendo, S., Roughgarden, J., Trumoer, K. \& Turner, R.K., Economic reasons for conserving wild nature. Science, 297(5583), pp. 950-953, 2002. 
[21] Wessels, K.J., Prince, S.D., Frost, P.E. \& Van Zyl, D., Assessing the effects of humaninduced land degradation in the former homelands of northern South Africa with a 1 km AVHRR NDVI time-series. Remote Sensing of Environment, 91, pp. 47-67, 2004.

[22] Van Schalkwyk, B., Schoeman, C. \& Cilliers, J., The interface between rural communities in South Africa and their urban counterparts: the significance for sustainable rural community development in the Vaalharts area. (In Marchettini, N., Brebbia, C.A., Pulselli, R. \& Bastianoni, S., The Sustainable City IX, WIT Press: Southampton and Boston, pp. 453-462), 2014.

[23] South Africa. Department of Rural Development and Land Reform. Strategic plan 2015-2020, Pretoria, 2015.

[24] Pallarès-Blanch, M., Prados, M.J. \& Tulla, A.F., Naturbanization and urban-rural dynamics in Spain: case study of new rural landscapes in Andalusia and Catalonia. European Countryside, 2, pp. 118-160, 2014.

[25] Bielsa, I., Pons, X. \& Bunce, B., Agricultural abandonment in the North Eastern Iberian peninsula: the use of basic landscape metrics to support planning. Journal of Environmental Planning and Management, 48(1), pp. 85-102, 2005.

[26] Audirac, I., Shermyen. A.H. \& Smith, M.T., Ideal urban form and good visions of the good life - Florida's growth management dilemma. Journal of the American Planning Association, 56(4), pp. 470-482, 1990.

[27] Vereijken, P.H., Transition to multifunctional land use and agriculture. Netherlands Journal of Agricultural Science, 50(2), pp. 171-179, 2002.

[28] Newman, G. \& Saginor, J., Priorities for advancing the concept of New Ruralism. Sustainability, 8(269), pp. 1-15, 2016.

[29] Lehmann, S., Green urbanism: formulating a series of holistic principles. Surveys and Perspectives Integrating Environment and Society, 3(2), pp. 1-10, 2010.

[30] Jepson, E.J. \& Edwards, M.M., How possible is sustainable urban development? An analysis of planners' perceptions about new urbanism, smart growth and the ecological. Planning Practice \& Research, 25(4), pp. 417-437, 2010.

[31] Trudeau, D., A typology of new urbanism in neighborhoods. Journal of Urbanism: International Research on Placemaking and Urban Sustainability, 6(2), pp.113-138, 2013.

[32] Kraus, S., A call for New Ruralism, https://frameworks.ced.berkeley.edu/2006/a-callfor-new-ruralism/. Accessed on: 23 Jun. 2017.

[33] Moffat, D., New ruralism: agriculture at the metropolitan edge [dispatch]. Places, 18(2), pp. 71-75, 2006.

[34] Versaci, R., New ruralism - developers are looking to our agrarian past to create communities. Old House Journal's New House. Spring 2008: 10-11. http://www.russellversaci.com/New_Ruralism.pdf. Accessed on: 30 Jun. 2017.

[35] Nelson, G.D., Towards the New Ruralism, Harvard University: Cambridge, pp. 1-85, 2009.

[36] Muschamp, H., Can New Urbanism Find Room for the Old? The New York Times, p. 27, 2 Jun. 1996.

[37] Beatley, T., Native to Nowhere: Sustaining Home and Community in a Global Age, Island Press: Washington DC, pp. 1-392, 2004.

[38] Mayo, J. M. \& Ellis, C., Capitalist dynamics and New Urbanist principles: junctures and disjunctures in project development. Journal of Urbanism: International Research on Placemaking and Urban Sustainability, 2(3), pp. 237-257, 2009. 
[39] Talen, E., The social goals of new urbanism. Housing Policy Debate, 13(1), pp. 165 188, 2002.

[40] Duany, A. \& Plater-Zyberk, E., The second coming of the American small town. The Wilson Quarterly, 16(1), pp. 19-48, 1992.

[41] Bohl, C.C., New urbanism and the city: potential applications and implications for distressed inner-city neighborhoods. Housing Policy Debate, 11(4), pp. 761-801, 2000.

[42] Moudon, A.V., Proof of goodness - a substantive basis for new urbanism? Places, 13(2), pp. 38-43, 2000.

[43] IURD (Institute of Urban and Regional Development) \& SAGE (Sustainable agriculture Education). Summary of workshop - Developing a framework for New Realism, held at the University of California, Berkeley, 7 April 2006. http://newruralism.pbworks.com/f/New\%20Ruralism\%20Workshop20060407.pdf. Accessed on: 25 Jun. 2017.

[44] Louw, M.P., The new urbanism and new ruralism frameworks as potential tools for sustainable rural development in South Africa. Stellenbosch, Stellenbosch University. (Thesis-Masters), pp. 1-134, 2012.

[45] SACN (South African Cites Network). State of South African cities report Johannesburg: SACN, 2016.

[46] McHarg, I.L., Design with Nature, Doubleday, New York, pp. 1-197, 1971.

[47] McHarg, I.L., Human ecological planning at Pennsylvania. Landscape Planning, 8, pp. 109-120, 1981.

[48] Howard, E., Tomorrow, A Peaceful Path to Real Reform. Garden Cities of Tomorrow, ATC Books/Faber and Faber: London, 1902.

[49] Sharifi, A., From garden city to eco-urbanism: the quest for sustainable neighbourhood development. Sustainable Cities and Society, 20, pp. 1-16, 2016.

[50] Artmann, M., Bastian. \& Grunewald, K., Using the concept of green infrastructure and ecosystem services to specify Leitbilder for compact and green cities - the example of the landscape plan of Dersden (Germany). Sustainability, 9(198), pp. 126, 2017.

[51] Ahern, J., From fail-safe to safe-to-fail: Sustainability and resilience in the new urban world. Landscape and Urban Planning, 100(4), pp. 241-343, 2011.

[52] Harrison, P., Bobbins, K., Culwick, C., Humby, T., La Mantia, C., Todes, A. \& Weakley, D., Urban Resilience - Thinking for Municipalities. University of the Witwatersrand, Gauteng City-Region Observatory, 2014.

[53] Tîrlă, M.L., Manea, G., Vijulie, I., Matei, E. \& Cocoş, O., Green cities - urban planning models of the future. In Efe, R., Sam, N., Sam, R., Spiriajevas, E. \& Galay, E. eds. Cities in the globalizing world and Turkey: a theoretical and empirical perspective. University Press: Sofia, Bulgaria, pp. 462-479, 2014.

[54] Adesina, A.A., Gurria, A. \& Helen, C. eds, African economic outlook: sustainable cities and structural transformation. Paris: OECD Publications.

[55] www.africaneconomicoutlook.org/sites/default/files/contentpdf/eBook_AEO2016.pdf Accessed on: 26 Jun. 2017. 2016.

[56] Beatley, T. \& Newman, P., Green urbanism down under, Island Press: Washington, pp.1-236, 2009.

[57] Nilsson, K; Åkerlund, U; Konijnendijk, C C.; Alekseev, A; Caspersen, O. H.; Guldager, S; Kuznetsov, E; Mezenko, A. \& Selikhovkin, A., Implementing urban 
greening aid projects - the case of St. Petersburg, Russia. Urban Forestry \& Urban Greening, 2(6) pp. 93-101, 2007.

[58] Palmer, H. \& Simon, D., Conclusions, implications and practical guidelines, (In Simon, D., Rethinking sustainable cities, Policy Press: Bristol and Chicago, pp. 145201), 2016.

[59] Cilliers, E.J. \& Cilliers, S.S., Planning for Green Infrastructure: Options for South African Cities. South African Cities Network, 2016.

[60] Rodenburg, C.A. \& Nijkamp, P., Multifunctional land use in the city: a typological overview. Built Environment, 30(4), pp. 274-288, 2004.

[61] GWA Studio, Verkykerskop Green Living Compendium (unpublished), 2014.

[62] Talen, E., Charter for the new urbanism, McGraw-Hill Education: New York, pp. 1301, 2013.

[63] Wilson, G., Multifunctional 'quality' and rural community resilience. Transactions of the Institute of British Geographers, 35(3), pp. 364-381, 2010.

[64] Schama, S., Landscape and Memory, New York: Alfred A. Knopf, p. 35, 1995. 